\title{
Indoor Radon Measurements Using Radon Track Detectors and Electret Ionization Chambers in the Bauxite-Bearing Areas of Southern Adamawa, Cameroon
}

\author{
Saïdou 1,2,*, Oumar Bobbo Modibo ${ }^{1,3}$, Ndjana Nkoulou II Joseph Emmanuel ${ }^{1}$, Olga German ${ }^{4}$, \\ Kountchou Noube Michaux ${ }^{1}$ and Hamadou Yerima Abba ${ }^{1}$ \\ 1 Nuclear Technology Section, Institute of Geological and Mining Research, Yaounde P.O. Box 4110, Cameroon; \\ bobbomodibo@gmail.com (O.B.M.); nndjana@yahoo.fr (N.N.II.J.E.); kountchounoube@yahoo.fr (K.N.M.); \\ hamadouyerima700@gmail.com (H.Y.A.) \\ 2 Faculty of Science, University of Yaounde I, Yaounde P.O. Box 812, Cameroon \\ 3 Institute of Radiation Emergency Medicine, Hirosaki University, 66-1 Honcho, Hirosaki-shi, \\ Aomori 036-8564, Japan \\ 4 Division of Radiation, Transport and Waste Safety, Department of Nuclear Safety and Security, \\ International Atomic Energy Agency, P.O. Box 100, 1400, Wagramer strasse, 1020 Vienna, Austria; \\ O.German@iaea.org \\ * Correspondence: saidous2002@yahoo.fr; Tel.: +237-674174473
}

Received: 24 June 2020; Accepted: 8 July 2020; Published: 17 September 2020

\begin{abstract}
The current work deals with indoor radon $\left({ }^{222} \mathrm{Rn}\right)$ concentrations and ambient dose-equivalent rate measurements in the bauxite-bearing areas of the Adamawa region in Cameroon before mining from 2022. In total, 90 Electret Ionization Chambers (EIC) (commercially, EPERM) and 175 Radon Track Detectors (commercially, RADTRAK ${ }^{2}$ ) were used to measure ${ }^{222}$ Rn concentrations in dwellings of four localities of the above region. A pocket survey meter (RadEye PRD-ER, Thermo Scientific, Waltham, MA, USA) was used for the ambient dose-equivalent rate measurements. These measurements were followed by calculations of annual doses from inhalation and external exposure. ${ }^{222} \mathrm{Rn}$ concentrations were found to vary between $36 \pm 8-687 \pm 35 \mathrm{~Bq} \mathrm{~m}^{-3}$ with a geometric mean (GM) of $175 \pm 16 \mathrm{~Bq} \mathrm{~m}^{-3}$ and $43 \pm 12-270 \pm 40 \mathrm{~Bq} \mathrm{~m}^{-3}$ with a geometric mean of $101 \pm 21 \mathrm{~Bq} \mathrm{~m}^{-3}$ by using EPERM and RADTRAK, respectively. According to RADTRAK data, 51\% of dwellings have radon concentrations above the reference level of $100 \mathrm{~Bq} \mathrm{~m}^{-3}$ recommended by the World Health Organization (WHO). The ambient dose equivalent rate ranged between 0.04-0.17 $\mu \mathrm{Sv} \mathrm{h}^{-1}$ with the average value of $0.08 \mu \mathrm{Sv} \mathrm{h}^{-1}$. The inhalation dose and annual external effective dose to the public were assessed and found to vary between $0.8-5 \mathrm{mSv}$ with an average value of $2 \mathrm{mSv}$ and $0.3-1.8 \mathrm{mSv}$ with an average value of $0.7 \mathrm{mSv}$, respectively. Most of the average values in terms of concentration and radiation dose were found to be above the corresponding world averages given by the United Nations Scientific Commission on the Effects of Atomic Radiation (UNSCEAR). Even though the current exposure of members of the public to natural radiation is not critical, the situation could change abruptly when mining starts.
\end{abstract}

Keywords: bauxite; radon; electret ionization chamber; radon track detector; external dose; inhalation dose

\section{Introduction}

Mining activities are increasing in Africa. Several countries have recently instituted a mining code to better organize this sector for their socio-economic sustainable development [1]. Like other countries, Cameroon has various mineral ore deposits; however, most of them have not yet 
been exploited. A national project on strengthening the capacities of the mining sector is being implemented by the Government of Cameroon [2]. The project resulted in new discoveries of more than three hundred anomalies of mineral resources. A large number of mineral resources, such as uranium, thorium, gold, diamond, bauxite, copper, rutile, cobalt, iron, and rare-earth metals, were discovered. Further exploration is required to confirm the occurrence of the ore deposits of the above mineral resources, which would rank Cameroon among the top countries with valuable underground mineral resources. Multiple activities were organized by the Government to promote mining in Cameroon. It is well known that mining leads to environmental pollution by naturally occurring radioactive materials (NORM) and heavy metals. For most human activities involving minerals and raw materials, the levels of exposure to these radionuclides are not significantly greater than normal background levels, and when these raw materials with low concentrations of NORM are introduced in an industrial process, the radionuclides can become more concentrated in the produced by-products or in waste material such as red mud in bauxite mining [3,4]. Such activities significantly increase the exposure of workers and the general public, meaning that they may need to be controlled by regulation in order to ensure the protection from radiation of relevant people. The most frequently-occurring radionuclides and their decay products found in bauxite and bauxite processing residuals include ${ }^{238} \mathrm{U}$, ${ }^{235} \mathrm{U}$, and ${ }^{232}$ Th series.

Bauxite ore is the primary source of aluminum in the world [5]. The ore must first be chemically processed to produce alumina (aluminum oxide), which is then smelted using an electrolysis process to produce pure aluminum metal. Bauxite is typically found in topsoil located in various tropical and subtropical regions. Bauxite reserves are most plentiful in Africa, Oceania and South America. Reserves are projected to last for centuries. Bauxite is a rock formed from a reddish clay material called laterite soil and is most commonly found in tropical or subtropical regions. Bauxite is primarily comprised of aluminum oxide compounds (alumina), silica, iron oxides and titanium dioxide. More than 160 million metric tons of bauxite are mined each year. The leaders in bauxite production include Australia, China, Brazil, India and Guinea. Bauxite reserves are estimated to be 55 to 75 billion metric tons, primarily spread across Africa (32\%), Oceania (23\%), South America and the Caribbean (21\%) and Asia (18\%).

The bauxite deposits of Minim-Martap and Ngaoundal in southern Adamawa, Cameroon will be exploited in the near future. Thus, pre-exploitation background radiation levels should be determined for the accurate assessment of the impact of mining on the environment and the general public in the post-exploitation environment [6-15]. In that perspective, field works were performed for soil and water sampling, radon detectors were deployed in dwellings and ambient equivalent dose rates measurements were performed. In this work, the results on radon measurements in 265 dwellings using two types of detectors (EPERM and RADTRAK), ambient-equivalent dose rates measurements both indoors and outdoors followed by inhalation and external dose assessments are reported. Additionally, the limitations of EPERM detectors compared to RADTRAK detectors are discussed.

\section{Materials and Methods}

\subsection{Study Areas}

The study areas are located in Djerem Division, in the southern part of Adamawa Region in Cameroon (Figure 1). The Division has about 200,000 inhabitants, with Tibati as the capital. Several bauxite deposits are located particularly in Ngaoundal and Minim-Martap. The region is mountainous and forms the barrier between the forest area of south Cameroon and the savannah area of North Cameroon. The climate is typically tropical Sudanese with two seasons: the dry season from November to April and rainy season from May to October. The annual rainfall varies between $900 \mathrm{~mm}$ to $1500 \mathrm{~mm}$. Temperatures vary between 10.1 to $41.6^{\circ} \mathrm{C}$, and the relative humidity varies between $10.2-99.9 \%$ throughout the year [16]. 


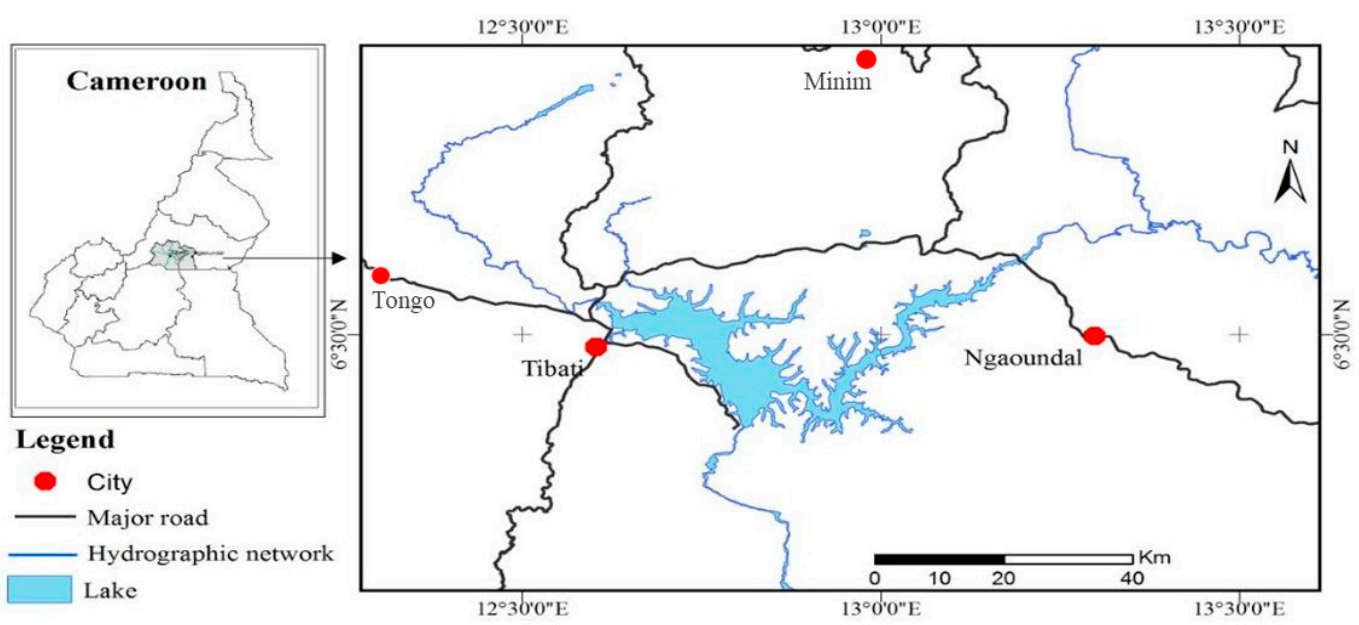

Figure 1. Location map of the bauxite bearing areas of southern Adamawa.

Canyon Resources is an Australian mining company which has exploration and mining permits covering several bauxite deposits in Cameroon, including in the Adamawa Region-the present study area [17]. Its local branch, Camalco SA, is focused on developing the Minim-Martap Bauxite Project (MMP). The MMP has identified a bauxite-rich plateau which was mapped after drilling and prospection across the surface. The total area covered by the permits is $1349 \mathrm{~km}^{2}$. The bauxite is generally high in alumina, with low total and reactive silica, high gibbsite, low boehmite and low amounts of other contaminants [18]. The total indicated resources are $839 \mathrm{Mt}$ at $45.2 \%$ of $\mathrm{Al}_{2} \mathrm{O}_{3}$ and $2.8 \%$ of $\mathrm{SiO}_{2}$. The bauxite also includes a high-grade (cut-off grade $45 \% \mathrm{Al}_{2} \mathrm{O}_{3}$ ) indicated resource of $431 \mathrm{Mt}$ at $48.8 \%$ of $\mathrm{Al}_{2} \mathrm{O}_{3}$ and $2.6 \%$ of $\mathrm{SiO}_{2}$ containing substantial zones of $>50 \%$ of $\mathrm{Al}_{2} \mathrm{O}_{3}$ with very low amounts of contaminants [17].

\subsection{Methodology}

\subsubsection{Electret Ionization Chamber}

E-PERM Electret Ion Chambers (EICs) were used to measure ${ }^{222} \mathrm{Rn}$ indoors. The E-PERM EICs were manufactured by Rad Elec Inc., Frederick, MD, USA. Detailed descriptions of their design and operation have been given in the Rad Elec Manual and also published in [19]. An EIC for monitoring radon consists of a stable electret (electrically charged Teflon ${ }^{\circledR}$ disc) mounted inside an electrically conducting chamber. The electret serves both as a source of the electric field and as a sensor. The ions produced inside the chamber are collected by the electret. The reduction in charge of the electret is related to the total ionization during the period of exposure. This charge reduction is measured using a battery-operated Electret Voltage Reader. Using appropriate calibration factors and exposure time, desired parameters such as airborne radon concentration in the air can be calculated.

Ninety EIC type LLT (Low Sensitivity L+ Electret Long Term LT) devices were randomly and equally distributed in Ngaoundal and Tibati-the most populated towns of Djerem Division, representing about $50 \%$ of people living in the Division. About 40,000 and 60,000 inhabitants live in Ngaoundal and Tibati, respectively. The exposure period was from December 2014 to February 2015 during the dry season. Although indoor radon concentrations are submitted to seasonal variations, no correction was carried out. Dwellings were selected randomly with an in-situ request addressed to the resident to place an EIC inside the house. EICs were exposed for two months relatively far from the open access of house to avoid biased measurements due to the influence of outdoor air and at $1 \mathrm{~m}$ above the ground. Most of the surveyed dwellings were built using locally made soil bricks, which were sometimes covered by a thick layer of cement. 
Radon concentrations were given by the following equation:

$$
\begin{gathered}
C_{R n}\left(\mathrm{~Bq} \mathrm{~m}^{-3}\right)=37 \times\left(\frac{I-F}{C F . D}-B G\right) f_{\text {corr }}^{a t t}\left(\mathrm{pCi} \mathrm{L}^{-1}\right) \\
C F=A+B \frac{I+F}{2}
\end{gathered}
$$

where $I$ and $F$ are the initial and final voltages of the electret expressed in volts [V], $C F$ is the calibration factor [ $\mathrm{V} / \mathrm{pCi} \mathrm{L^{-1 }}$ days], $D$ is the duration of the exposure [days], $B G$ is the background due to the ambient dose expressed in radon equivalent concentration $\left[\mathrm{pCi} \mathrm{L}^{-1}\right]$ and $f_{\text {corr }}^{\text {att }}$ is the correction factor taking into account of the dwelling altitude (alt) above sea level. The fitting parameters $A$ and $B$ are given by the manufacturer as $A=0.02383$ and $B=0.0000112$.

$$
\begin{gathered}
B G=0.120 \frac{\mathrm{pCi} \mathrm{L}^{-1}}{\mu \mathrm{R} \mathrm{h}}{ }^{-1} \\
f_{\text {corr }}^{\text {att }}=0.996+0.00016 . \operatorname{alt}(\mathrm{m})
\end{gathered}
$$

EICs are sensitive to background gamma radiation. The equivalent radon signal in picocuries per liter ( $\left.\mathrm{pCi} \mathrm{L}{ }^{-1}\right)$ per unit background radiation in micro-roentgens per hour $\left(\mu \mathrm{R} \mathrm{h}^{-1}\right)$ is determined by the manufacturer depending on the type of EIC. This is specific to the chamber and not to the electret used in the chamber. This parameter is 0.12 for $\mathrm{L}$ chambers. This value must be multiplied by the gamma radiation level at the site (in $\mu \mathrm{R} \mathrm{h}^{-1}$ ) and the product (in equivalent $\mathrm{pCi} \mathrm{L}^{-1}$ ) subtracted from the apparent radon concentration. The default value of the background was used for the present study.

The minimum voltage before exposing the EIC is fixed at $200 \mathrm{~V}$. The accuracy of measurements is ensured by using a radon reference chamber for quality control checking before each set of electret readings using the Electret Voltage Reader. The voltage of the reference chamber when provided by the manufacturer is $(248 \pm 1) \mathrm{V}$. This voltage is supposed to decrease less than $1 \mathrm{~V}$ each year and should not be used for many years.

The precision was monitored in the present study by placing 10 EICs in the same conditions in a dwelling for three months. The arithmetic mean of the indoor radon concentration and the standard deviation were determined. The corresponding precision was determined to be $10 \%$ [6].

Regarding the uncertainty assessment, three sources of uncertainty were identified: (1) uncertainty $u_{1}$, regarding the active volume and electret thickness of the EIC estimated at $5 \%$;

(2) uncertainty $u_{2}$, related to the initial and final readings of the electret estimated at $1.4 \mathrm{~V}$;

(3) uncertainty $u_{3}$, regarding the gamma external radiation, estimated between $0.1-0.2 \mathrm{pCi} \mathrm{L} \mathrm{L}^{-1}$. The uncertainties of the temperature, humidity and ventilation system were neglected.

Finally, the overall relative uncertainty combining all the above components was evaluated by using the following equation:

$$
u=\sqrt{u_{1}^{2}+u_{2}^{2}+u_{3}^{2}}
$$

\subsubsection{Closed Alpha-Track Detector (RADTRAK ${ }^{2 \circledR}$ )}

A number of 175 RADTRAK detectors were deployed in Ngaoundal, Minim, Tibati and Tongo from May to June 2019. A total of 169 detectors were collected after two months of exposure time and sent back to the RADONOVA Laboratories for analysis in Uppsala, Sweden. The measurement was performed following the standard ISO 11665-4 [20]. The detector container was manufactured from electrically conducting plastic. Through a small slit (filter), radon gas entered the detector. The track-detecting material (film) inside the detector is was then by alpha particles generated by the radon entering the container and the decay products formed from it. On the film, the alpha particles made small tracks which are enlarged with chemical etching and later counted in a microscope in order to determine the radon exposure. The lowest detection limit for a measurement period of 3 months is $10 \mathrm{~Bq} \mathrm{~m}^{-3}$. 
The arithmetic mean of radon activity concentration $\left(\mathrm{Bq} \mathrm{m}^{-3}\right)$ is given as follows:

$$
\begin{gathered}
\bar{C}=\left(n_{g}-\bar{n}_{b}\right) \frac{1}{t . S_{S S N T D} \cdot F_{c}}=\left(n_{g}-\bar{n}_{b}\right) \cdot \omega \\
\omega=\frac{1}{t . S_{S S N T D} \cdot F_{c}}
\end{gathered}
$$

where $n_{g}$ is the number of tracks after exposure, $\bar{n}_{b}$ is the mean number of tracks caused by the background radiation, $t$ is the sampling duration, $F_{c}$ is the calibration factor, $\omega$ is the correction factor linked to the calibration factor and the sampling duration and $S_{S S N T D}$ is the detector area used for counting the number of etched tracks in $\mathrm{cm}^{2}$.

For the most accurate value, $\bar{n}_{b}$ is determined experimentally by reading $n$ detectors that have not been exposed to radon and have been processed under the same physico-chemical and counting conditions. The value of $\bar{n}_{b}$ may also be given by the manufacturer.

The standard uncertainty of $\bar{C}$ is given as follows:

$$
\begin{aligned}
u(\bar{C})= & \sqrt{\left(n_{g}+\frac{\bar{n}_{b}}{n}\right) \cdot \omega^{2}+\bar{C}^{2} \cdot u_{r e l}^{2}(\omega)} \\
& u_{r e l}^{2}(\omega)=u_{r e l}^{2}\left(F_{c}\right)+u_{r e l}^{2}(S)
\end{aligned}
$$

where $u_{r e l}$ is the relative standard uncertainty. The uncertainty of the sampling duration is considered negligible.

\subsubsection{Inhalation Dose}

The inhalation dose due to the exposure to radon is given as follows:

$$
E_{i n h}=A_{i n h} \times e_{i n h} \times F_{o c c} \times F_{e q} \times t
$$

where $A_{\text {inh }}$ is the geometric mean of radon concentration, $e_{i n h}$ is the inhalation dose conversion factor of $9 \mathrm{nSv} /\left(\mathrm{Bq} \mathrm{h} \mathrm{m}{ }^{-3}\right), F_{o c c}$ is the occupancy factor of 0.6 for the study areas, $F_{e q}$ is the equilibrium factor of 0.4 which is the default value given by UNSCEAR [21] and $t$ corresponds to one year expressed in hours.

It should be mentioned that the conversion factor proposed by UNSCEAR [21] has recently been called into question by the International Commission on Radiological Protection (ICRP) [22], which suggests a correction by a factor of 2 upwards. In 2017, the ICRP published new, higher dose conversion factors for radon, which therefore increased the calculated radiation dose associated with exposure to radon in workplaces [23]. For the calculation of doses following the inhalation of radon and radon progeny in underground mines and in buildings, in most circumstances, the ICRP recommends a dose coefficient of $3 \mathrm{mSv}$ per $\mathrm{mJ} \mathrm{h} \mathrm{m}{ }^{-3}$ (approximately $10 \mathrm{mSv} \mathrm{WLM}^{-1}$ ).

UNSCEAR, however, has confirmed in a report on lung cancer from exposure to radon in 2019 that the evidence reviewed by its experts is compatible with the available data in the Committee's previous assessment of lung cancer risk due to radon [24]. Therefore, UNSCEAR concluded that there is no reason to change its established dose conversion factor and recommends the continued use of the dose conversion factor of $9 \mathrm{nSv}$ per $\left(\mathrm{Bq} \mathrm{h} \mathrm{m}{ }^{-3}\right)$ EEC of ${ }^{222} \mathrm{Rn}$, which corresponds to $1.6 \mathrm{mSv}\left(\mathrm{mJ} \mathrm{h} \mathrm{m}^{-3}\right)^{-1}$ for estimating radon exposure levels to a population. This new report was approved by the Fourth Committee of the United Nations General Assembly in October 2019.

Finally, it is clear that the uncertainty in the dose conversion factor should be taken into consideration when assessing inhalation dose due to radon indoors.

\subsubsection{External Effective Dose}

The Thermo Scientific RadEye PRD detector was used to measure the ambient dose-equivalent rates prior to external dose assessment. It is a high-sensitivity gamma radiation detection and dose 
rate measurement tool incorporating a highly sensitive $\mathrm{NaI}(\mathrm{TI})$ scintillation detector with a miniature photomultiplier for the detection of gamma radiation levels.

The radiation exposure from external sources is the result of natural and artificial ground radiation as well as from the cosmic background. The value of the external effective dose is given by

$$
E_{\text {ext }}(m S v)=\left[\left(1-F_{o c c}\right) H_{o u t}+F_{o c c} \times H_{\text {in }}\right] \times t
$$

where $H_{\text {out }}$ and $H_{\text {in }}$ are the arithmetic mean of the outdoor and indoor ambient equivalent dose rates and $F_{o c c}$ is the occupancy factor of 0.6 determined previously by Saïdou et al. [6].

\section{Results and Discussion}

\subsection{Indoor Radon Distribution Using Electret Ionization Chambers (EPERM)}

From the total of 90 EPERM detectors deployed, 69 were returned in a usable condition in laboratory for the final voltage reading and radon concentration deduction. Figures 2 and 3 display the distributions of indoor radon concentrations in Tibati and Ngaoundal, respectively. The minimum and maximum radon concentrations were $36 \mathrm{~Bq} \cdot \mathrm{m}^{-3}$ and $569 \mathrm{~Bq} \mathrm{~m} \mathrm{~m}^{-3}$ in Tibati, $37 \mathrm{~Bq} \mathrm{~m}^{-3}$ and $687 \mathrm{~Bq} \mathrm{~m}^{-3}$ in Ngaoundal respectively. The corresponding arithmetic and geometric means were $195 \mathrm{~Bq} \mathrm{~m}^{-3}$ and $150 \mathrm{~Bq} \mathrm{~m}^{-3}$ in Tibati, $270 \mathrm{~Bq} \mathrm{~m}^{-3}$ and $205 \mathrm{~Bq} \mathrm{~m}^{-3}$ in Ngaoundal, respectively. These values are clearly above the world arithmetic mean of $40 \mathrm{~Bq} \mathrm{~m}^{-3}$ [21]. It has been proven that elevated radon concentrations indoors depend on several factors such as the building material, radon exhalation rate from the ground and house ventilation rate [25-28]. In most surveyed dwellings, the buildings were poorly ventilated and were made out of soil bricks. Such conditions could explain the high indoor radon concentrations. In its recent Publication 126 [29], the International Commission on Radiological Protection (ICRP) strongly encouraged national authorities to set national reference levels in the range of $100-300 \mathrm{~Bq} \mathrm{~m}^{-3}$ by taking into account the socio-economic factors of the country. It was found that $70 \%$ and $15 \%$ of surveyed dwellings had radon concentrations above $100 \mathrm{~Bq} \mathrm{~m}{ }^{-3}$ and $300 \mathrm{~Bq} \mathrm{~m}^{-3}$, respectively. In view of the latest scientific data, the WHO proposed a reference level of $100 \mathrm{~Bq} \mathrm{~m}^{-3}$ to minimize health hazards due to indoor radon exposure [30]. If this level cannot be reached by taking into account the Gross Domestic Product (GDP) of the country, the chosen reference level should not exceed $300 \mathrm{~Bq} \mathrm{~m}^{-3}$ in houses.



(A)

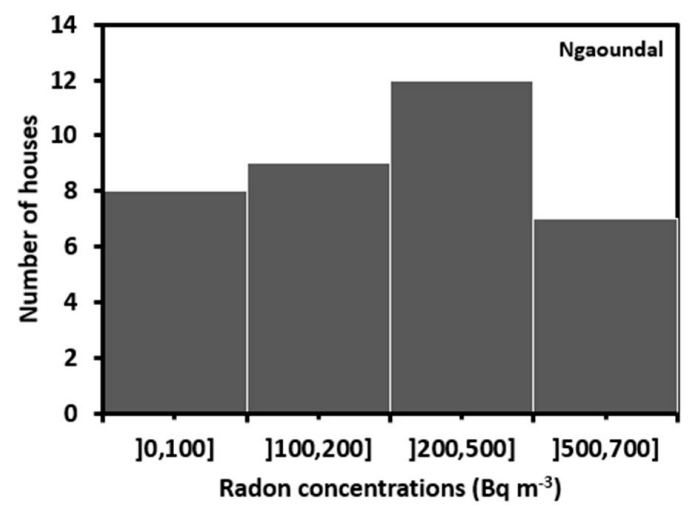

(B)

Figure 2. Distribution of radon in dwellings of Tibati (A) and Ngaoundal (B) using EPERM detectors. 


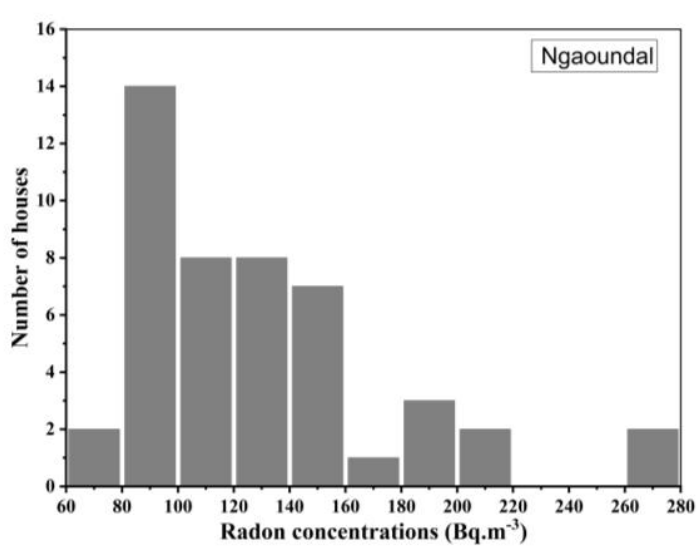

(A)

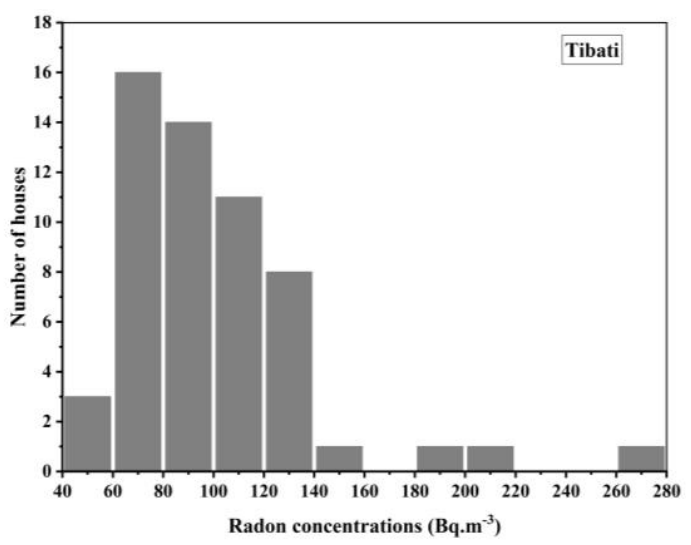

(B)

Figure 3. Lognormal distribution of ${ }^{222} \mathrm{Rn}$ in houses of Ngaoundal (A) and Tibati (B) using RADTRAK detectors. The numbers of houses are 48 and 56 in Ngaoundal and Tibati, respectively.

\subsection{Indoor Radon Distribution Using Radon Track Detectors (RADTRAK)}

As shown in Table $1,{ }^{222} \mathrm{Rn}$ concentrations were found to vary between $43 \pm 12$ and $270 \pm 40 \mathrm{~Bq} \mathrm{~m}^{-3}$ with a geometric mean of $102 \pm 21 \mathrm{~Bq} \mathrm{~m}^{-3}$. It was also found that $51 \%$ of dwellings had radon concentrations above the reference level of $100 \mathrm{~Bq} \mathrm{~m}^{-3}$ recommended by the WHO [21]. About $4 \%$ of dwellings had radon concentrations higher than $200 \mathrm{~Bq} \mathrm{~m}^{-3}$. No dwelling had a radon concentration above $300 \mathrm{~Bq} \mathrm{~m}^{-3}$. Radon concentrations in Ngaoundal and Minim ranged between $68 \pm 14$ and $262 \pm 40 \mathrm{~Bq} \mathrm{~m}^{-3}$ and $43 \pm 12$ and $172 \pm 30 \mathrm{~Bq} \mathrm{~m}^{-3}$, respectively, with corresponding GMs of $123 \pm 24 \mathrm{~Bq} \mathrm{~m}{ }^{-3}$ and $85 \pm 18 \mathrm{~Bq} \mathrm{~m}^{-3}$, respectively. Radon concentrations in Tibati and Tongo ranged between $56 \pm 14$ and $270 \pm 40 \mathrm{~Bq} \mathrm{~m}^{-3}$ and $72 \pm 14$ and $174 \pm 30 \mathrm{~Bq} \mathrm{~m}^{-3}$, respectively, with corresponding GMs of $93 \pm 20 \mathrm{~Bq} \mathrm{~m}^{-3}$ and $105 \pm 21 \mathrm{~Bq} \mathrm{~m}^{-3}$. As shown in Figure 4 radon distribution in the whole study area follows lognormal law.

Table 1. Activity concentrations of ${ }^{222} \mathrm{Rn}$ determined by using Radon Track (RADTRAK) detectors. AM: arithmetic mean, SD: standard deviation, GM: geometric mean, GSD: geometric standard deviation, $\mathrm{N}$ : number of dwellings.

\begin{tabular}{cccccc}
\hline \multirow{2}{*}{ Statistical Parameters } & \multicolumn{3}{c}{ Radon Concentration (Bq m $\mathbf{~} \mathbf{3}^{\mathbf{3}}$} & \\
& Ngaoundal & Tibati & Tongo & Minim & Whole Study Area \\
\hline Range & $68-262$ & $56-270$ & $72-174$ & $43-172$ & $43-270$ \\
AM \pm SD & $131 \pm 25$ & $99 \pm 21$ & $107 \pm 22$ & $91 \pm 19$ & $108 \pm 22$ \\
GM \pm GSD & $123 \pm 24$ & $93 \pm 20$ & $105 \pm 21$ & $85 \pm 18$ & $102 \pm 21$ \\
Median & 123 & 94 & 104 & 82 & 100 \\
N & 48 & 56 & 31 & 32 & 167 \\
\hline
\end{tabular}

The above values were compared with other results from ore-bearing or mining regions of Cameroon [6-15]. Indoor radon concentrations ranged between $46-143 \mathrm{~Bq} \mathrm{~m}^{-3}$ in Poli [12], $27-937 \mathrm{~Bq} \mathrm{~m}^{-3}$ in Lolodorf [15], 88-282 $\mathrm{Bq} \mathrm{m}^{-3}$ in Betare-Oya [9], and 31-436 Bq m${ }^{-3}$ in the coastal city of Douala [11]. The average values were $82 \mathrm{~Bq} \mathrm{~m}^{-3}, 97 \mathrm{~Bq} \mathrm{~m}^{-3}, 133 \mathrm{~Bq} \mathrm{~m}^{-3}$ and $139 \mathrm{~Bq} \mathrm{~m}^{-3}$, respectively. In total, $20 \%$ of dwellings had radon concentrations above $100 \mathrm{~Bq} \mathrm{~m}^{-3}$ in the uranium-bearing region of Poli, $47 \%$ in the uranium-bearing region of Lolodorf, $76 \%$ in the gold mining areas of Betare-Oya and $27 \%$ in Douala city. No house had a radon concentration above $300 \mathrm{~Bq} \mathrm{~m}^{-3}$ in Poli and Douala city. Only $1 \%$ of houses had a radon concentration above $300 \mathrm{~Bq} \mathrm{~m}^{-3}$ in Lolodorf, and $3 \%$ in Betare-Oya. These results indicate a large variation in the radon level in houses. It is clear that the above data make a real contribution to radon-risk mapping in the country. 


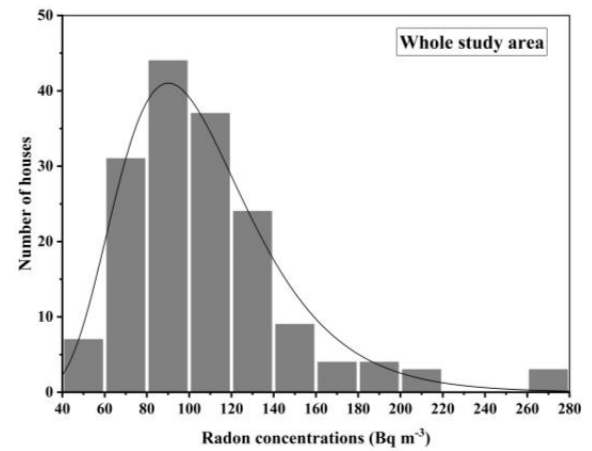

(A)

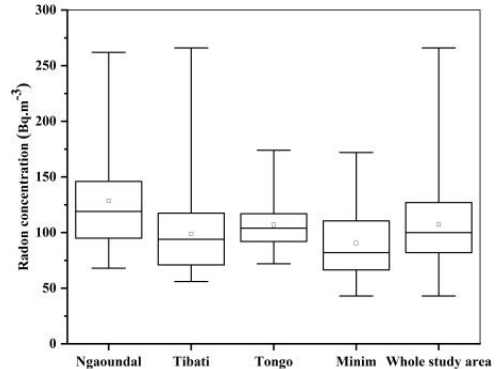

(B)

Figure 4. Lognormal distribution (A) of indoor ${ }^{222} \mathrm{Rn}$ in the bauxite-bearing Southern Adamawa. Boxplot distribution (B) is made for each study area and the whole bauxite-bearing areas. The total number of RADTRAK detectors analyzed was 169 . Box plot refers to median, lower and upper quartiles. Outliers are shown on either side of the rectangular box at the limit of the vertical line. The small filled circle above the median represents the arithmetic mean.

As evidenced in Figure 5, the Pearson correlation factor of 0.4 shows that the correlation between the indoor ambient-equivalent dose rate and ${ }^{222} \mathrm{Rn}$ concentration is low in the bauxite-bearing areas of southern Adamawa in Cameroon. This low correlation reveals an independence between indoor gamma radiation and radon concentration due to the good ventilation of dwellings. Doors and windows are diurnally open.

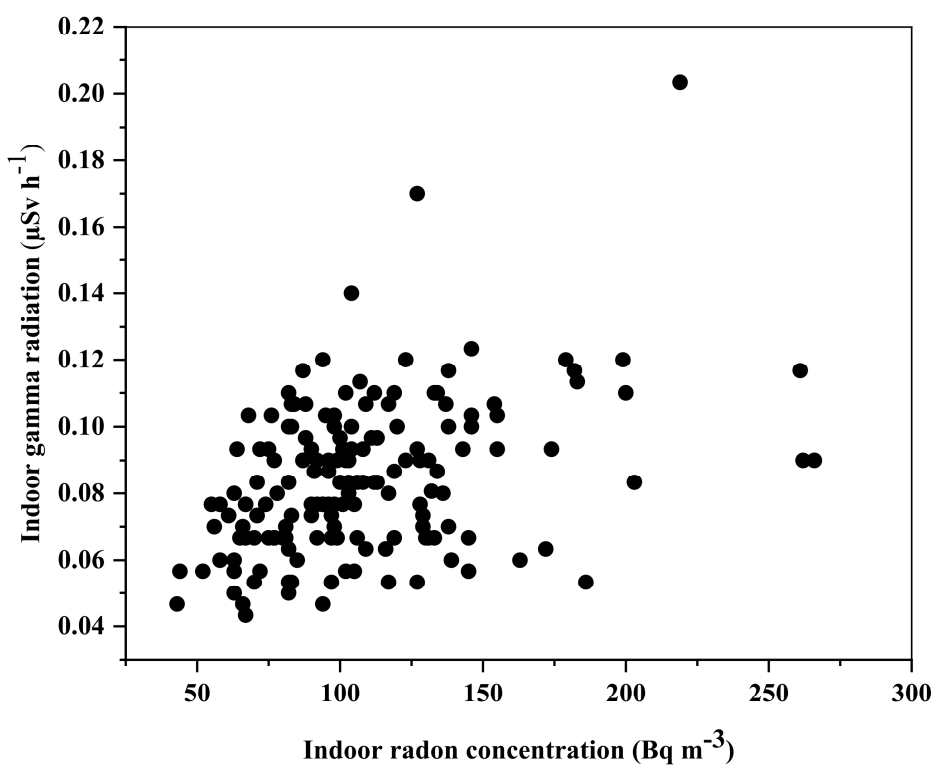

Figure 5. Correlation between indoor ambient-equivalent dose rate and indoor radon in the bauxite-bearing areas of southern Adamawa.

\subsection{Comparison of the Results Obtained with EPERM and RADTRAK}

Wide differences were observed between results given by EPERM and RADTRAK detectors. Table 2 shows the coefficient of the ratio between EPERM and RADTRAK, which varied greatly from 0.80 to 2.50 . Moreover, the Z-score test on the two sets of data confirmed the wide difference between most of the values belonging to the two sets of data (EPERM and RADTRAK). EPERM is a detector based on the principle of electrostatic collection; it has been shown that this type of detector is greatly affected by humidity, such as with the Electrostatic Radon Monitor developed by Iida et al. [31]. Furthermore, Sorimachi et al. [32] showed how humidity, ambient aerosols and thoron influence the 
detection responses of EIC detectors. The present study area is a humid climate area with a yearly humidity ranging between 10-99\% [18]. This could explain the great difference between the two sets of data. Furthermore, the dwellings surveyed by EPERM detectors in 2015 are not in general those where ${ }^{222} \mathrm{Rn}$ was measured in 2019 using RADTRAK detectors.

Table 2. Ratio (RADTRAK/ EPERM) activity concentrations of indoor ${ }^{222} \mathrm{Rn}$ and Z-score test.

\begin{tabular}{|c|c|c|c|c|}
\hline $\begin{array}{l}{ }^{222} \mathrm{Rn} \text { Concentration } \\
\left(\mathrm{Bq} \mathrm{m}^{-3}\right) \text { by EPERM }\end{array}$ & $\begin{array}{l}{ }^{222} \mathrm{Rn} \text { Concentration } \\
\left(\mathrm{Bq} \mathrm{m}^{-3} \text { ) by RADTRAK }\right.\end{array}$ & Type & $\begin{array}{c}\text { Ratio } \\
\text { (RADTRAK/EPERM }\end{array}$ & Z-Score \\
\hline $36 \pm 8$ & $43 \pm 12$ & Minimum & 0.80 & -0.48 \\
\hline $687 \pm 35$ & $270 \pm 40$ & Maximum & 2.50 & 7.8 \\
\hline $233 \pm 20$ & $108 \pm 22$ & Arithmetic mean & 2.20 & 4.23 \\
\hline $175 \pm 16$ & $101 \pm 21$ & Geometric mean & 1.70 & 2.8 \\
\hline
\end{tabular}

\subsection{External Effective Dose}

Table 3 shows that the external effective dose in the studied areas of Ngaoundal, Minim, Tongo and Tibati ranges between $0.3-1.8 \mathrm{mSv}$ with an arithmetic mean of $0.7 \pm 0.2 \mathrm{mSv}$. It ranges between 0.6-1.8 mSv in Ngaoundal, $0.3-0.7 \mathrm{mSv}$ in Minim, $0.5-0.8 \mathrm{mSv}$ in Tibati and 0.6-0.9 mSv in Tongo. The corresponding arithmetic means are $0.9 \pm 0.2 \mathrm{mSv}, 0.5 \pm 0.1 \mathrm{mSv}, 0.6 \pm 0.1 \mathrm{mSv}$ and $0.8 \pm 0.1 \mathrm{mSv}$, respectively. Most of these values are lower than the world average value of $0.9 \mathrm{mSv}(0.5 \mathrm{mSv}$ for terrestrial radiation and $0.4 \mathrm{mSv}$ for cosmic radiation) given by UNSCEAR [21]. Currently, the exposure of members of the public to external sources is not critical. The situation could change in Ngaoundal and Minim, which are most close to the bauxite deposits. According to Canyon Resources, mining will start in 2022, with a consequent increase in the external dose due to NORM.

Table 3. External and inhalation dose to members of the public in the bauxite-bearing areas of Southern Adamawa. AM: arithmetic mean, SD: standard deviation, GM: geometric mean, GSD: geometric standard deviation, N: number of dwellings.

\begin{tabular}{|c|c|c|c|c|c|}
\hline & \multirow[b]{2}{*}{ Statistical Parameters } & \multicolumn{3}{|c|}{ External Effective Dose (mSv) } & \multirow[b]{2}{*}{ Inhalation Dose (mSv) } \\
\hline & & Outdoor (Out) & Indoor (In) & $\begin{array}{l}\text { Total Dose } \\
\text { (Out + In) }\end{array}$ & \\
\hline \multirow{5}{*}{ Ngaoundal } & Range & $0.20-0.70$ & $0.39-1.07$ & $0.64-1.77$ & $1.29-4.96$ \\
\hline & $\mathrm{AM} \pm \mathrm{SD}$ & $0.31 \pm 0.08$ & $0.56 \pm 0.12$ & $0.86 \pm 0.18$ & $2.43 \pm 0.87$ \\
\hline & GM(GSD) & $0.30 \pm 1.24$ & $0.54 \pm 1.20$ & $0.85 \pm 1.18$ & $2.30 \pm 1.38$ \\
\hline & Median & 0.30 & 0.53 & 0.82 & 2.26 \\
\hline & $N$ & 48 & 48 & 48 & 48 \\
\hline \multirow{5}{*}{ Tibati } & Range & $0.18-0.30$ & $0.28-0.54$ & $0.50-0.84$ & $1.06-5.04$ \\
\hline & $\mathrm{AM} \pm \mathrm{SD}$ & $0.23 \pm 0.03$ & $0.39 \pm 0.05$ & $0.62 \pm 0.06$ & $1.87 \pm 0.72$ \\
\hline & GM(GSD) & $0.23 \pm 1.14$ & $0.39 \pm 1.14$ & $0.62 \pm 1.12$ & $1.77 \pm 1.39$ \\
\hline & Median & 0.23 & 0.38 & 0.62 & 1.78 \\
\hline & $N$ & 56 & 56 & 56 & 56 \\
\hline \multirow{5}{*}{ Tongo } & Range & $0.21-0.35$ & $0.35-0.63$ & $0.63-0.94$ & $1.36-3.30$ \\
\hline & $\mathrm{AM} \pm \mathrm{SD}$ & $0.27 \pm 0.03$ & $0.50 \pm 0.07$ & $0.77 \pm 0.08$ & $2.03 \pm 0.40$ \\
\hline & GM(GSD) & $0.27 \pm 1.13$ & $0.49 \pm 1.16$ & $0.77 \pm 1.10$ & $1.99 \pm 1.21$ \\
\hline & Median & 0.28 & 0.49 & 0.78 & 1.97 \\
\hline & $N$ & 31 & 31 & 31 & 31 \\
\hline \multirow{5}{*}{ Minim } & Range & $0.07-0.26$ & $0.23-0.44$ & $0.30-0.68$ & $0.81-3.26$ \\
\hline & $\mathrm{AM} \pm \mathrm{SD}$ & $0.17 \pm 0.03$ & $0.31 \pm 0.05$ & $0.48 \pm 0.07$ & $1.72 \pm 0.62$ \\
\hline & GM(GSD) & $0.17 \pm 1.26$ & $0.31 \pm 1.16$ & $0.48 \pm 1.17$ & $1.62 \pm 1.43$ \\
\hline & Median & 0.18 & 0.30 & 0.48 & 1.55 \\
\hline & $N$ & 32 & 32 & 32 & 32 \\
\hline \multirow{5}{*}{ Whole study area } & Range & $0.07-0.70$ & $0.23-1.70$ & $0.30-1.77$ & $0.81-5.04$ \\
\hline & $\mathrm{AM} \pm \mathrm{SD}$ & $0.25 \pm 0.07$ & $0.44 \pm 0.11$ & $0.70 \pm 0.18$ & $2.03 \pm 0.75$ \\
\hline & GM(GSD) & $0.24 \pm 1.32$ & $0.43 \pm 1.30$ & $0.67 \pm 1.28$ & $1.92 \pm 1.40$ \\
\hline & Median & 0.25 & 0.43 & 0.68 & 1.90 \\
\hline & N & 166 & 166 & 166 & 166 \\
\hline
\end{tabular}




\subsection{Inhalation Dose}

As displayed in Table 3, the inhalation dose of the studied areas ranged between $0.8-5 \mathrm{mSv}$ with an average value of $2.0 \pm 0.7 \mathrm{mSv}$. It ranged between $1.3-5 \mathrm{mSv}, 0.8-3.3 \mathrm{mSv}, 1.1-5 \mathrm{mSv}$ and 1.4-3.3 mSv in Ngaoundal, Minim, Tibati and Tongo. respectively. The corresponding average values are $2.4 \pm 0.9 \mathrm{mSv}, 1.7 \pm 0.6 \mathrm{mSv}, 1.9 \pm 0.7 \mathrm{mSv}$ and $2.0 \pm 0.4 \mathrm{mSv}$, respectively. All the average values were higher than the world average value of $1.2 \mathrm{mSv}$ given by UNSCEAR [21]. Saïdou et al. [10] previously reported natural radiation exposure to the public in some mining and ore-bearing regions of Cameroon. It has been found that the average inhalation doses due to ${ }^{222} \mathrm{Rn}$ are $1.5 \mathrm{mSv}, 2 \mathrm{mSv}, 2.5 \mathrm{mSv}$ and $2.6 \mathrm{mSv}$ in the uranium-bearing region of Poli [12], the uranium and thorium-bearing region Lolodorf [15], the gold mining areas of Betare-Oya [9] and the coastal city of Douala [11], respectively. It can be noted that the above average values are comparable to those found in the current work. As shown in Figure 6, the inhalation dose distribution of indoor radon follows the lognormal law.

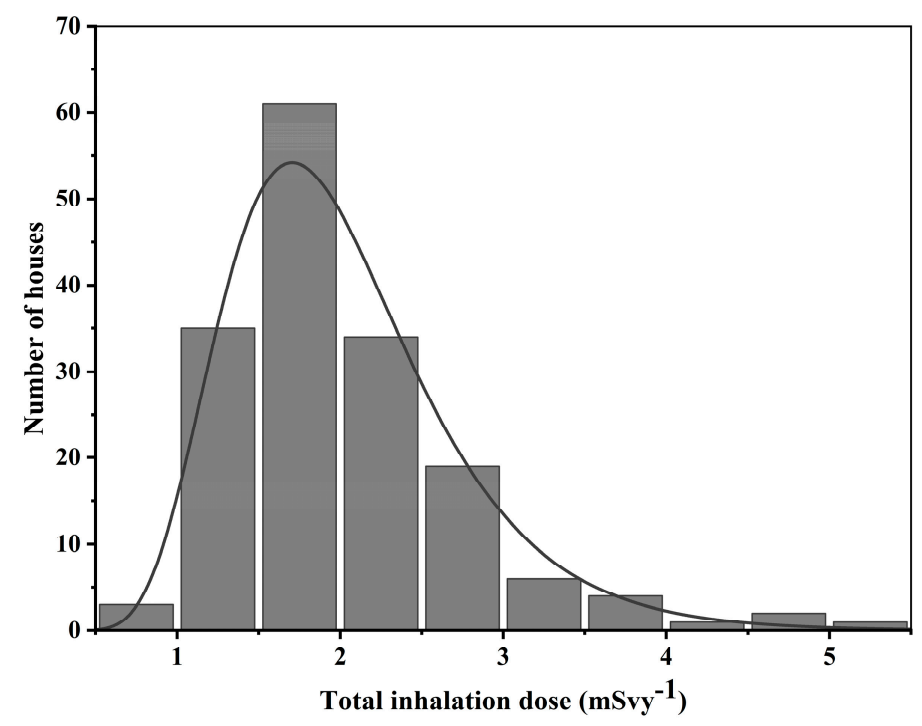

Figure 6. Lognormal distribution of inhalation dose due to ${ }^{222} \mathrm{Rn}$ in dwellings in the bauxite-bearing areas of Southern Adamawa.

\section{Conclusions}

In this work, ${ }^{222} \mathrm{Rn}$ was measured in 265 dwellings of the bauxite-bearing areas of southern Adamawa in Cameroon using EPERM and RADTRAK detectors followed by indoor and outdoor ambient equivalent dose rate measurements before the commencement of mining in 2022 . The ${ }^{222} \mathrm{Rn}$ concentrations were found to vary between $43-270 \mathrm{~Bq} \mathrm{~m}^{-3}$, with a geometric mean of $101 \mathrm{~Bq} \mathrm{~m}^{-3}$-higher than the world average value of $40 \mathrm{~Bq} \mathrm{~m}^{-3}$. It was also found that $51 \%$ of dwellings have radon concentrations above the reference level of $100 \mathrm{~Bq} \mathrm{~m}^{-3}$. The inhalation dose due to ${ }^{222} \mathrm{Rn}$ exposure ranges between $0.8-5 \mathrm{mSv}$ with an average value of $2 \mathrm{mSv}$ - higher than world average value of $1.2 \mathrm{mSv}$. The external effective dose ranges between $0.3-1.8 \mathrm{mSv}$ with an average value of $0.7 \mathrm{mSv}-$ lower than the world average value of $0.9 \mathrm{mSv}(0.5 \mathrm{mSv}$ for terrestrial radiation and $0.4 \mathrm{mSv}$ for cosmic radiation) given by UNSCEAR. It clearly appears that the exposure level is not critical. The situation could change in the near future during mining activity. Thus, radiation protection measures should be applied to avoid the spread of NORM in the environment. Furthermore, the current results will contribute in the ongoing project of establishing national reference levels for indoor radon in Cameroon within the framework of the setup of the National Radon Action Plan and regulations of radon exposure.

Author Contributions: Data curation, Saïdou, O.B.M., N.N.II.J.E., K.N.M. and H.Y.A.; Formal analysis, Saïdou, O.B.M. and N.N.II.J.E.; Investigation, Saïdou, O.B.M., N.N.II.J.E., O.G. and K.N.M.; Project administration, O.G.; Resources, O.G.; Supervision, Saïdou; Writing_review \& editing, Saïdou. All authors have read and agreed to the published version of the manuscript. 
Funding: This research was funded by the International Atomic Energy Agency within the framework of the Technical Cooperation Project CMR9009 and by the Ministry of Scientific Research and Innovation through BIP 2018.

Acknowledgments: Radon measurements using RADTRAK detectors were carried out in the framework of the IAEA TC project CMR9009 titled "Establishing a national radon plan for controlling public exposure due to radon indoors". The International Atomic Energy Agency (IAEA) is thanked for their funding and technical support. Oscar Meless and Olga German, IAEA Programme Management Officer and Technical Officer, respectively, are acknowledged for their involvement in the success of CMR9009. The Ministry of Scientific Research and Innovation of Cameroon is acknowledged for funding the field works through the Public Investment Budget 2018 allocated to the Institute of Geological and Mining Research. The National Liaison Officer with IAEA, Simo Augustin, is thanked for his valuable contribution to the management of CMR9009. Samba Richard Ndi of the National Radiation Protection Agency, Cameroon is thanked for the transport of RADTRAK detectors for analysis.

Conflicts of Interest: The authors declare no conflict of interest.

\section{References}

1. Mining Code. Cameroon Law No. 2016/017. 14 December 2016. Available online: https: //www.prc.cm/fr/actualites/actes/lois/2316-loi-n-2016-017-du-14-decembre-2016-portant-code-minier-ducameroun?highlight=WyJjb2RliiwibWluaWVyliwiY29kZSBtaW5pZXIiXQ==(accessedon4July2020).

2. Capacity Building Project in the Mining Sector. Available online: https://min-midtgov.com/precasem/ (accessed on 4 July 2020).

3. Kovacs, T.; Bátor, G.; Schroeyers, W.; Labrincha, J.; Puertas, F.; Hegedus, M.; Nicolaides, D.; Sanjuán, M.; Krivenko, P.; Grubeša, I.; et al. From raw materials to NORM by-products. Nat. Occur. Radioact. Mater. Constr. 2017, 2017, 135-182. [CrossRef]

4. Hegedús, M.; Tóth-Bodrogi, E.; Jónás, J.; Somlai, J.; Kovács, T. Mobility of 232 Th and 210 Po in red mud. J. Environ. Radioact. 2018, 185, 71-76. [CrossRef] [PubMed]

5. Bauxite. Available online: https://www.aluminum.org/industries/production/bauxite (accessed on 7 July 2020).

6. Saïdou; Abdourahimi; Siaka, Y.T.; Bouba, O. Indoor radon measurements in the uranium regions of Poli and Lolodorf, Cameroon. J. Environ. Radioact. 2014, 136, 36-40. [CrossRef]

7. Saïdou; Tokonami, S.; Janik, M.; Bineng Guillaume, S.; Abdourahimi; Ndjana Nkoulou, J.E., II. Radon-thoron discriminative measurements in the high natural radiation areas of southwestern Cameroon. J. Environ. Radioact. 2015, 150, 242-246. [CrossRef]

8. Saïdou; Abiama, P.E.; Tokonami, S. Comparative study of natural radiation exposure to the public in three uranium and oil regions of Cameroon. Radioprotion 2015, 50, 265-271. [CrossRef]

9. Ndjana Nkoulou, J.E., II; Ngoa Engola, L.; Hosoda, M.; Bongue, D.; Suzuki, T.; Kudo, H.; Kwato Njock, M.G.; Tokonami, S. Simultaneous indoor radon, thoron and thoron progeny measurements in betare-oya gold mining areas, eastern cameroon. Radiat. Prot. Dosim. 2019, 185, 391-401. [CrossRef]

10. Saïdou; Tokonami, S.; Hosoda, M.; Ndjana Nkoulou, J.E., II; Akata, N.; Tchuente Siaka, Y.F.; Modibo, O.B.; Samuel, B.G.; Takoukam Soh, S.D. Natural radiation exposure to the public in mining and ore bearing regions of cameroon. Radiat. Prot. Dosim. 2019, 184, 391-396. [CrossRef]

11. Takoukam Soh, S.D.; Tokonami, S.; Hosoda, M.; Suzuki, T.; Kudo, H.; Bouba, O.; Saïdou. Simultaneous measurements of indoor radon and thoron and inhalation dose assessment in Douala City, Cameroon. Isot. Environ. Heal. Stud. 2019, 55, 499-510. [CrossRef] [PubMed]

12. Saïdou; Shinji, T.; Hosoda, M.; Tchuente Siaka, Y.F.; Ndjana Nkoulou, J.E., II; Naofumi, A.; Oumar Bobbo, M.; Penaye Joseph. Natural radiation exposure to the public in the uranium bearing region of Poli, Cameroon: From radioactivity measurements to external and inhalation dose assessment. J. Geochem. Explor. 2019, 205, 106350. [CrossRef]

13. Oumar Bobbo, M.; Saïdou; Ndjana Nkoulou, J.E., II; Suzuki, T.; Kudo, H.; Hosoda, M.; Owono, L.C.O.; Tokonami, S. Occupational Natural Radiation Exposure at the Uranium Deposit of Kitongo, Cameroon. Radioisotopes 2019, 68, 621-630. [CrossRef]

14. Bineng, G.S.; Saïdou; Hosoda, M.; Tchuente Siaka, Y.F.; Akata, N.; Ele Abiama, P.; Bouba, O.; Tokonami, S. External radiation exposure to the public using car-borne survey method in the uranium and thorium bearing region of Lolodorf, Cameroon. Radiat. Environ. Med. 2020, 9, 13-20. 
15. Bineng, G.S.; Tokonami, S.; Hosoda, M.; Tchuente Siaka, Y.F.; Issa, H.; Suzuki, T.; Kudo, H.; Bouba, O.; Saïdou. The Importance of Direct Progeny Measurements for Correct Estimation of Effective Dose Due to Radon and Thoron. Front. Public Heal. 2020, 8, 17. [CrossRef] [PubMed]

16. CAL, Cameroon Alumina Limited, Etude d'Impact Environnemental et Social du Projet d'Exploitation des Gisements de Bauxite de Minim-Martap et Ngaoundal dans la Région de l'Adamaoua, République du Cameroun; India and Rainbow Environment Consulting: Yaoundé, Cameroon, 2010. (In French)

17. Canyon Resources Limited. [Internet]. Available online: https://www.canyonresources.com.au/minimmartap-project (accessed on 3 May 2020).

18. Canyon Resources Limited. Company Announcement. 6 August 2019. Available online: https://static1.squarespace.com/static/5b9cbcb58f5130f854d93dad/t/5de0bd0bd36d6241f15842d3/1575009553272/ 190927+Significant+Resource+upgrade+at+Minim+Martap.pdf (accessed on 3 May 2020).

19. Kotrappa, P.; Stieff, L.R.; Bigu, J. E-PERM Radon Flux Monitors for Measuring Undisturbed Radon Flux from the Ground. In Proceedings of the 1996 International Radon Symposium II; Available online: http://aarst-nrpp.com/proceedings/1996/1996_13_Passive_E_Perm_Radon_Flux_Monitors_ For_Measuring_Und.pdf. (accessed on 3 May 2020).

20. ISO11665-4, Measurement of Radioactivity in the Environment-Air: Radon-222, Part 4: Integrated Measurement Method for Determining Average Activity Concentration Using Passive Sampling and Delayed Analysis (2020). Available online: https://www.iso.org/standard/76009.html (accessed on 3 May 2020).

21. United Nations Scientific Committee on the Effects of Atomic Radiation (UNSCEAR). Sources and Effects of Ionizing Radiation; United Nations Publication: Vienna, Austria, 2000.

22. International Commission on Radiological Protection (ICRP). Lung Cancer Risk from Radon and Progeny and Statement on Radon; ICRP Publication 115, Part 1; Pergamon Press: Oxford, UK, 2010.

23. International Commission on Radiological Protection (ICRP). Occupational intakes of radionuclides: Part 3; ICRP Publication 137; Pergamon Press: Oxford, UK, 2017.

24. United Nations Scientific Committee on the Effects of Atomic Radiation (UNSCEAR). Report of the UNSCEAR to 66th General Assembly of the United Nations; United Nations Publication: Vienna, Austria, 2019.

25. Janik, M.; Omori, Y.; Yonehara, H. Influence of humidity on radon and thoron exhalation rates from building materials. Appl. Radiat. Isot. 2015, 95, 102-107. [CrossRef] [PubMed]

26. Nazaroff, W.W. Radon transport from soil to air. Rev. Geophys. 1992, 30, 137. [CrossRef]

27. Gusain, G.; Prasad, G.; Prasad, Y.; Ramola, R.C. Comparison of indoor radon level with radon exhalation rate from soil in Garhwal Himalaya. Radiat. Meas. 2009, 44, 1032-1035. [CrossRef]

28. Andersen, C.E. Numerical modelling of radon-222 entry into houses: An outline of techniques and results. Sci. Total. Environ. 2001, 272, 33-42. [CrossRef]

29. International Commission on Radiological Protection (ICRP). Radiological Protection against Radon Exposure, ICRP Publication 126; Pergamon Press: Oxford, UK, 2014.

30. WHO, World Health Organization. WHO Handbook on Indoor Radon, a Public Health Perspective; WHO Press: Geneva, Switzerland, 2009.

31. Iida, T.; Ikebe, Y.; Suzuki, K.; Ueno, K.; Wang, Z.; Jin, Y. Continuous measurements of outdoor radon concentrations at various locations in East Asia. Environ. Int. 1996, 22, 139-147. [CrossRef]

32. Sorimachi, A.; Takahashi, H.; Tokonami, S. Influence of the presence of humidity, ambient aerosols and thoron on the detection responses of electret radon monitors. Radiat. Meas. 2009, 44, 111-115. [CrossRef]

(C) 2020 by the authors. Licensee MDPI, Basel, Switzerland. This article is an open access article distributed under the terms and conditions of the Creative Commons Attribution (CC BY) license (http://creativecommons.org/licenses/by/4.0/). 